\title{
Yabancı Dil Olarak Türkçe Öğretiminde Kullanılan Ders Kitaplarının Ünite Değerlendirme Ölçütleri Bağlamında Analizi*
}

\section{Ramazan Şimşek ${ }^{1}$}

Tahsin Aktaş²

\section{Öz}

Type/Tür:

Research/Araştırma

Received/Geliş Tarihi:

November 1/1 Kasim 2019

Accepted/Kabul Tarihi: May 19/

19 Mayıs 2020

Page numbers/Sayfa No: 708-728

Corresponding

Author/İletişimden Sorumlu

Yazar:

ramazansimsek@nevsehir.edu.tr

\section{$\checkmark$ iThenticate}

This paper was checked for plagiarism using iThenticate during the preview process and before publication. / Bu çalışma ön inceleme sürecinde ve yayımlanmadan önce iThenticate yazılımı ile taranmıştır.

Copyright (C) 2017 by

Cumhuriyet University, Faculty of Education. All rights reserved.
Tarihsel süreç içinde eğitim ve öğretimde en sık kullanılan, öğretici ve öğrenci için rehber mahiyetinde bulunan materyal, ders kitabı olarak kabul edilmektedir. Ders kitapları, ölçme ve değerlendirme açısından eğitim süreçlerinin anahtar materyali konumundadır. Yabancı dil eğitimi açısından ders kitapları, kaliteyi etkileyen araçlardır. Yabancı dil eğitimi kapsamında da öğrencilerin düzeyi ve dil gelişimi gözetilerek ders kitapları hazırlanmakta ve dil eğitiminde de çok sık kullanılmaktadır. Temel dil becerileri açısından birbiri ile bütünleşik içerikler, öğrenilenlerin kalıcılığını artırmakta olup ders kitabının önemini etkilemektedir. Bu materyallerin uluslararası standartlara göre düzenlenmesi sürecin verimliliğini etkilemektedir. Yabancı dil olarak Türkçe öğretiminde son yıllarda kullanılan materyal sayısının arttığı bilinmekte olup materyal nitelikleri üzerine çalışmaların sayısı da doğru orantılı olarak artmaktadır. $\mathrm{Bu}$ araştırmada da yabancılara Türkçe öğretiminde kullanılan İstanbul Yabancılar İçin Türkçe Öğretim Seti B2 düzeyi ders kitabı, doküman analizi yöntemi kullanılarak Ünite Değerlendirme Ölçütleri kapsamında incelenmiştir. İçerik analizi ve etkinliklerin fonksiyonları, kıstaslarla değerlendirilmiştir. Ünite değerlendirme ölçütleri kapsamında değerlendirilen ders materyalinde görsel ve içerik uyumu, temel dil becerilerini kapsayıcı bir yapılandırmanın hakim olduğu gözlemlenmiştir. İstanbul Yabancilar İçin Türkçe Öğretim Seti B2 düzeyi ders kitabının alıştırma tipleri okuma becerisi etkinlikleri ile öne çıktığ1 gözlemlenmiştir. Temel dil becerileri bağlamında, etkinlik sayıları ile ilgili düzenlemelere gidilmesi gerektiği tespit edilmiş olup düzenlemeler önerilmiştir.

Anahtar Kelimeler: Yabancılara Türkçe öğretimi, ders kitabı, ünite değerlendirme ölçütleri, okuma, dinleme,

\section{Suggested APA Citation/Önerilen APA Atıf Biçimi: \\ Şimşek, R., \& Aktaş, T. (2020). Yabancı dil olarak Türkçe öğretiminde kullanılan ders kitaplarının ünite değerlendirme ölçütleri bağlamında analizi. Cumhuriyet International Journal of Education, 9(3), 708-728. http://dx.doi.org/10.30703/cije.641716} \footnotetext{
Karşılaştırmalı Olarak İncelenmesi" başlıklı tezden üretilmiştir

1 Öğr. Gör. Dr, Nevşehir Hacı Bektaş Veli Üniversitesi, TÖMER Nevşehir/Türkiye

Lecturer, TÖMER, Nevşehir/Turkey

e-mail: ramazansimsek@nevsehir.edu.tr ORCID ID: orcid.org/0000-0002-8295-8903

2 Prof. Dr., Başkent Üniversitesi, Yabancı Diller Bölümü, Ankara/Türkiye

Prof. Dr., Baskent University, Department of Foreign Language, Ankara/Turkey

e-mail: tahsnak06@gmail.com ORCID ID: orcid.org/0000-0002-4232- 7453
}

*Bu çalışma “Yabancılara Türkçe Öğretiminde Kullanılan Ders Kitaplarının Temel Dil Becerileri Bağlamında 


\title{
Analysis of Course Books Used in Teaching Turkish as A Foreign Language in the Context of Unit Assessment Criteria
}

\begin{abstract}
In the historical process, the most commonly used material in education and training is the textbook that is used as a guide for the instructor and the student. Textbooks are key materials of educational processes in terms of assessment and evaluation. Textbooks in terms of foreign language education are tools that affect quality. Within the scope of foreign language education, textbooks are prepared considering the level of students and language development and they are used frequently in language education. Integral content in terms of basic language skills increases the permanence of what is learned and affects the importance of the textbook. Regulation of these materials according to international standards affects the efficiency of the process. It is known that the number of materials used in teaching Turkish as a foreign language has increased in recent years. In addition, the number of studies on material properties is increasing in direct proportion. In this study, Istanbul B2 level textbook which is used in teaching Turkish to foreigners has been examined within the scope of Unit Evaluation Criteria by using document analysis method. Visual and content harmony and an extensive structuring of basic language skills are observed in the course material. Istanbul B2 level textbook has been observed to come to the fore with exercise types reading skill activities. In the context of basic language skills, it was determined that the regulations regarding the number of activities should be made and the regulations were proposed.
\end{abstract}

Keywords: Teaching Turkish to foreigners, textbooks, common application text for languages, reading, listening

\section{Giriş}

Tarihsel süreç içerisinde doğrudan ya da dolaylı olarak iletişim kuran insanoğlunun en büyük bildirişim aracı dildir. Dil, insanların düşündüklerini ve duyduklarını bildirmek için kelimelerle veya işaretlerle yaptıkları anlaşma, lisandır (Türkçe Sözlük, 2005: 526). Dil, bir toplumda düşünce duygu ve isteklerin ses ve anlam yönünden ortak olan öğeler ve kurallardan yararlanılarak başkalarına aktarılmasını sağlayan çok yönlü, çok gelişmiş bir dizgedir (Aksan, 1977: 55).

Üzerinde onlarca tanım yapılan "dil" kavramı özelinde anadili dışındaki diller, ilk çağlarda siyaset, ticaret, kültür vb. sebepler ile seçkin topluluklar tarafından öğrenilirken 20 ve 21. yüzyılda küçük bir köy haline gelen dünya ile son derece geniş kitlerle buluşmuş ve yabancı dil öğrenimi önemli bir ekonomik sektör haline gelmiştir. Yabancı dil öğretimi, tarihsel süreç içerisinde insanlı̆̆ın sosyal, siyasal, eğitimsel, kültürel vb. uğraşlarının bileşkesinde bulunan en köklü uğraşlar içeresinde yer almıştır. İnsanoğlunun kullandığı diller, iletişimi sağlamak için çeşitli kurallar ve sistemler dâhilinde teşkilatlanmıştır. Bu teşkilatlanma yeryüzünde giderek büyüyen insan nüfusunu ve farklı dilleri konuşan toplulukları birbirinden ayırmış; çeşitli gerekçelerle yabancı dillerin öğrenilmesini sağlamıştır. Bu kapsamda, diğer insan toplulukları ile iletişime geçme, sosyo-kültürel etkileşimlerde bulunma amacıyla yabancı dil bilme ve öğrenme günümüzde oldukça önemlidir.

Yaşamın her alanında olduğu gibi eğitimde de hızlı bir değişim ve dönüşüm görülmektedir. Bunun doğal bir sonucu olarak insanlar kendilerini küresel bir etkileşim çemberinin içinde bulmaktadırlar. Bu durum, bir yabancı dil öğrenme ihtiyacını doğurmaktadır. Bu küresel etkileşim içerisinde etkin olan ulusların dilleri 
de doğal olarak önem kazanmaktadır. Bu bağlamda, Türkiye ve Türkçenin öneminin artması, Türkçenin yabancı dil olarak öğretiminin önemini ortaya çıkartmaktadır (Göçer, Moğul, 2011: 798).

Türkiye' nin üzerinde bulunduğu coğrafya, siyasal ve toplumsal anlamda aktif dinamikleri bünyesinde barındırılmaktadır. Bu dinamiklerle beraber içinde bulunduğumuz coğrafyada demografik ve sosyopolitik fay hatlarındaki hareketlenmeler ülkemize gelen yabancı sayısını ciddi miktarlarda artırmıştır. Ayrıca, Yurtdışı Türkler ve Akraba Topluluklar Başkanlığı bünyesinde son 10 yılda ülkemize burslu olarak gelen yabancı öğrenci sayısı da ciddi artış göstermiştir.

Kaynak: https://istatistik.yok.gov.tr/

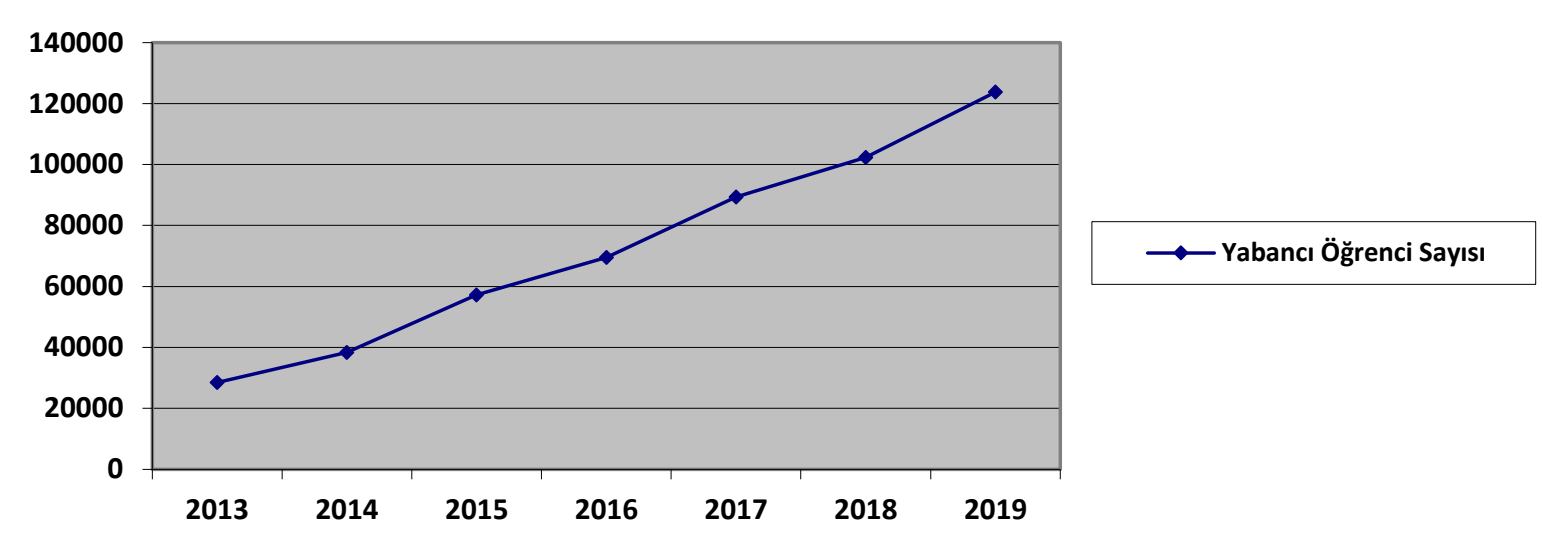

Şekil 1. Yıllara göre Türkiye' deki üniversitelere kayıt yaptıran yabancı öğrenci sayısı

Tüm bu faktörlerin bileşkesi olarak hitap edilen kitlenin milyonları aşmasıyla eğitim, öğrenim, adaptasyon ihtiyacı açı̆̆a çıkmış; yabancı dil olarak Türkçe öğretimi sürecin lokomotifi haline gelmiştir. Bu bağlamda, açı̆̆a çıkan ihtiyacı giderme maksadıyla üniversiteler bünyesinde hizmet veren Türkçe Öğretim Merkezleri (TÖMER) kurulmuştur. Bu kurumlarda dört temel dil becerisi ile birlikte gramer bilgisi Yabancı dil olarak Türkçe öğretimi sürecinin ana bileşenlerini oluşturmaktadır. Her TÖMER süreç içinde bir ders kitabı ve ders kitabı muhtevasında yer alan bir öğretim programı kullanmaktadır.

\section{Ders Kitabı}

Ders kitapları ile ilgili olarak alanyazında çeşitli tanımlamalar mevcuttur. Cunnigsworth (1995: 7) "un ders kitabı tanımı " Öğrenci ihtiyaçları ile ilgili olarak, önceden belirlenmiş amaç ve hedefleri sağlayan kaynak" şeklindedir. Ders kitabı, bir eğitim programında yer alan hedef, içerik, öğretme-öğrenme süreci ile ölçme değerlendirme boyutlarına uygun olarak hazırlanmış ve öğrenme amaçlı kullanılan basılı bir öğretim materyalidir (Demirel ve Kıroğlu, 2005:9).

Eğitim sürecinin planlanması ve bu planlamanın uygulayıc1, denetleyici aktörlerinin en büyük yardımcıları ders kitaplarıdır. Yabancı dil eğitimi de bu bağlamda önceden planlanan ve sadece dile ait bilgilerin ötesinde bir muhtevaya sahiptir. Temel dil becerileri ekseninde verilen yabancı dil eğitimi için kullanılan eğitim araçları ve materyaller sürecin mihenk taşları içinde yer almaktadır. Ders kitapları, yabancı dil eğitimi boyunca öğrenciye de öğretmene de rehberlik ederek bir program çerçevesinde dilin aşama aşama öğretimini üstlenir.(Gün, Şimşek, 2017: 503). 
Ders kitapları sadece çocuk ve gençlerin değil yetişkinlerin eğitiminde de etkin bir şekilde kullanılmaktadır. Okulda yapılan öğrenme ve öğretme süreçlerinde kullanılan eğitim araçları arasında ders kitapları "tamamlayıcı öğretim materyalleri" olmanın yanında, temel eğitim sürecinde sadece öğrencilerin değil, yetişkinlerin de öğrenme yaşantılarına kaynaklık ederler (Çalık, 2001: 1). Bazı araştırmacılara göre ise eğitim sürecinin temel materyalidir: "Ders kitapları, eğitimin amaçlarını gerçekleştirmek üzere öğrencinin öğrenme yaşantılarına kaynaklık eden öğretim materyallerinden biri, hatta birçok durumda tek öğretim materyalidir" (Halis, 2002: 51). Birçok dil öğretim programında ders kitabı kilit unsur olarak görülmektedir. Bazı durumlarda ders kitabı öğrencilerin elde ettiği kazanımların ve sınıfta yapılan dilsel uygulamaların çoğuna kaynaklık eder (Brown, 1998). Kayda değer bir konuma sahip olan ders kitapları öğretmen ve öğrenen arasında köprü görevi üstlenirken sürecin ana faktörü öğretmen ve öğrenci açısından önemli faydaları bulunmaktadır:

- Ders kitabı, eğitim sürecinin sistematik bir program ve bilişsel etkileşim sürecinde gitmesini sağlarken zamanın verimli kullanılmasına yardımcı olur.

- Ders içeriğinin aktarım şeklini ve aktarılacak kapsamı dizayn eder.

- Öğretim sürecinde muhatap olan kitlenin öğrenme modellerini keşfetmede öğreticiye yardımcı olur.

- Ders dışı öğrenme ortamları oluşturarak bağımsız çalışma becerisi kazandirir.

- Öğrenilenlerin pekiştirilmesi ve tekrar edilmesini sağlar

- Eğitim kurumlarının ve düzenleyicilerinin süreç içinde kültür, değerler eğitimi, toplumsal duyarlılıklar gibi konuları kitleye örtük olarak iletme imkânı sunar.

Ölçme ve değerlendirme açısından süreci kolaylaştıran, öğrenilenlerin pekişmesini sağlayan, sürecin yönetiminde eşgüdüm sağlayan kaynak yine ders kitaplarıdır.

Türkçenin yabancı dil olarak öğretimi alanında ders kitapları ile ilgili yapılan çalışmaların sayısı artmaktadır. Bu bağlamda, Batı dillerinin sistematik şekilde yabancı dil olarak öğretimi süreciyle kıyaslandığında Türkçenin öğretiminde kullanılan materyallerin belirli niteliklere sahip olması gerekmektedir. Bu kapsamda, ders kitapları ve materyaller uluslararası standartlar etrafında şekillendirilmeli ve incelenmelidir.

\section{Ders Kitabı İnceleme ve Ünite Standartları}

Ders kitapları, salt olarak bilgi içerikli olarak algılansa da hitap ettiği kitle açısından zihinsel, kültürel ve temel dil becerileri ekseninde çok yönlü işlevsel materyallerdir. Türkçenin yabancı dil olarak öğretimi ile ilgili süreç, son 10 yılda oldukça ivmelenmiş ve materyal çeşitliliğinde de bu aksiyonla doğru orantılı bir seyir gözlemlenmiştir. Materyal çeşitliliğindeki nicel artışın araştırmacılar tarafından niteliğe yansıyıp yansımadığı önemli araştırma konularından birini teşkil etmektedir.

Ders kitabı ya da ders materyallerinin niteliği, sürecin verimlilik içinde sürdürülmesi için dikkat edilmesi gereken hususlardan biridir. Bu kapsamda, yabancı dil eğitimi kitapları için uluslararası standartlar ve nitelikler bakımından McGrath'ın (2002) çalışması alan yazın açısından önem arz etmektedir. 
McGrath (2002), çalışmasında genel görünüm, fiziksel görünüm, içerik, alıştırma ve değerlendirme başlıkları üzerinde durmuştur.

- Genel Görünüm: Bu başlık altında metinde yeterli açıklamaların olup olmadığı, ilgili yöntem tekniklerin kullanımı, etkinliklerin ve testlerin varlığı ve yönergelerin ilerleyişi gibi başlıklara değinilmiştir.

- Fiziksel Görünüm: Ders kitabı açısından son derece önemli özelliklerin incelendiği kısım, fiziksel görünüm kısmıdır. Ünite girişleri ve ders kitabı kapağının renklendirilmesi ve kitabın albenisi, sayfa düzeni, resimleme, sınıf düzeyi ve özelliklerine hitap etme gibi maddeleri bünyesinde barındırır.

- İçerik: Ders kitabında kullanılan dil yapısı, etkinliklerin tamamlayıcı özellikleri, seçilen konuların günlük hayatı içinde barındırması, öğrenci düzeyine uygunluğu, metinlerin üniteyle ilişkili olmaları, ünitenin becerilerle ilgili olma durumu vb. özellikler bu başlık altında incelenir.

- Alıştırma ve Değerlendirme: Ders kitabı bünyesindeki alıştırma ve değerlendirmelerin dört temel beceriyi geliştirici nitelikte olması, edinimlerin ölçülmesine yönelik etkinlik ve alıştırmaların olması, alıştırmaların düzeye uygunluğu gibi maddeler bu başlık altında incelenir.

McGrath (2002), üzerinde durduğu kavramlar değerlendirildiğinde öğretim programı ile ilgili öğeler, fiziksel ve görsel öğeler, içeriğin aktarım yöntemleri ders kitabının verimliliğini doğrudan etkileyen unsurlar olarak öne çıkmaktadır. Belirtilen tüm faktörlerin bileşimi yetkin bir ders materyalini sürece dâhil edecektir.

\section{Yöntem}

$\mathrm{Bu}$ çalışma, Türkçenin yabancı dil olarak öğretiminde kullanılan ders kitaplarının ünite değerlendirme ölçütleri aracılığıyla analiz edilmesine dayanan nitel bir araştırmadır. Bu araştırmada, araştırma modellerinden doküman analizi yöntemi kullanılmıştır. Doküman analizi yöntemi, araştırılacak konunun amaca uygun kaynaklarla birlikte, ortaya çıkacak verilerin sağlıklı olup olmamasında değerlendirilir (Çepni, 2007). Doküman analizi, çalışılması gereken ünitelerle alakalı yazılmış veya basılmış belgelerin analizini oluşturur (Yıldırım ve Şimşek, 2006).

Tüm dil eğitimi araç ve gereçlerinde olduğu gibi yabancı dil olarak Türkçe öğretiminde de kullanılan araç ve materyallerinin uluslararası standartları taşıması esastır. Bu çerçevede Materials Evaluation and Design for Language Teaching (McGrath, 2002:240) da yer alan yabancı dil eğitimi materyallerinin ünitelerinin değerlendirilmesi için geliştirilen çalışma bünyesinde kullanılan genel görünüm, fiziksel görünüm, içerik, alıştırma ve değerlendirme maddeleri uzman görüşü alındıktan sonra "ünite değerlendirme boyutu” isimli nitel değerlendirme formunda ölçüt olarak kullanılmıştır,

\section{Veri Toplama Araçları}

Araştırmaya kaynaklık eden veriler, araştırmacı tarafından uzman görüşü alınarak hazırlanan Ünite Değerlendirme Ölçütleri aracılığıyla elde edilmiştir. McGrath'ın, (2002 :240) çalışmasından hareketle uzman görüşü alınarak oluşturulan Ünite Değerlendirme Ölçütleri aşağıdaki maddelerden oluşmaktadır:

1. Ünitede yer alan görseller metin içeriğine ve hedef kültüre ait öğelerin aktarımina uygun mu? 
2. Ünitede yer alan temalar öğrencilerin iletişim ihtiyaçlarına ve sosyal hayata uygun mu?

3. Ünite bünyesindeki metinler anlaşılır bir dille ve okumaya özendirici bir şekilde yazılmış mi?

4. Ünitede yer alan metinler dilbilgisi konularını işleyici ve sistematik olarak tüm becerilerde pekiştirici olarak verilmiş mi?

5. Ünitelerde yer alan alıştırmalar dört temel dil becerisini geliştirici ve bütünleyici mi?

6. Alıştırmalarda (boşluk doldurma, eşleştirme, doğru yanlış, kısa cevaplı sorular, çoktan seçmeli sorular vb.) çeşitlilik sağlanmış mı?

7. Ünite bünyesindeki dil becerilerine verilen önem eşit mi?

\section{Verilerin Analizi}

İstanbul Yabancılara Türkçe Öğretim Seti B2 düzey ders kitab1 ünite içerikleri, Ünite Değerlendirme Ölçütleri kapsamında nitel olarak analiz edilmiş ve bulgular tablolar eşliğinde sunulmuştur.

\section{Bulgular}

Çalışma kapsamında İstanbul Yabancılar İçin Türkçe Öğretim seti B2 düzeyi ders kitabının 6 ünitesi incelenmiştir.

Tablo 1

İstanbul Yabancılar İçin Türkçe Seti B2 Ders Kitabı 1.Ünitesinin (Leyleği havada Görmek) Ünite Değerlendirme Ölçütleri Kapsamında Değerlendirilmesi

\footnotetext{
1)Ünitede yer alan görseller Seyahat temasının hâkim olduğu ünite kapsamında kullanılan metin içeriğine ve hedef kültüre görseller beceri etkinlikleri ve içerik ile uyumludur Bavul ait öğelerin aktarımına uygun görselleri, tatil görselleri ve hedef kültür kapsamında Meryem Ana mu?

Evi isimli mekânın görselleri kullanılarak kültür aktarımı ilkesi gözetilmiştir

2)Ünitede yer alan temalar Ünite seyahat, yolculuk, bavul hazırlama ve turizm konuları öğrencilerin iletişim ihtiyaçlarına üzerine yapılandırılmıştır. Öğrencilerin rutin hayatlarının bir ve sosyal hayata uygun mu? parçası olan bu kavramlar gerçek iletişim ortamları ve işlevsel dil özelliklerinin kullandırıldığı beceri etkinlikleri ile işlenmiş ve öğrencilerin iletişim becerilerinin geliştirilmesi amaçlanmıştır. Hedef kültür açısından Meryem Ana Evi isimli okuma metininden faydalanılmış, dünya kültürüne yönelik olarak turizm çeşitlerinden bahsedilmiştir.

3)Ünite bünyesindeki metinler Ünite bünyesinde yer alan okuma metinleri ve dinleme metinleri anlaşılır bir dille ve okumaya öğrencilerin rutin olarak karşılaştıkları konular içinden seçilmiştir. özendirici bir şekilde yazılmış Seyahat, yolculuk öncesi hazırlık ve turizm konularının işlendiği mi? metinlerde kültür aktarımı ilkesi de gözetilerek bu konular hakkında çeşitli bilgiler verilmiştir. Ayrıca öğrencilerin kelime haznelerini geliştirmeleri amacıyla hedef kelimelerden de faydalanılmıştır. Seyahat konulu metinler öğrencilerin seyahat öncesinde yaptıkları hazırlıklar, neler yapmaları gerektiği vb. konuları işlemiştir. Meryem Ana Evi isimli metinde öğrencilere mekânın tarihsel kökenleri ve insanlık için önemi aktarılmıştır.
} 


\begin{abstract}
4)Ünitede yer alan metinler Üç bölümden oluşan ünitenin ilk bölümünde dönüşlü fiiller dilbilgisi konularını işleyici ve dilbilgisi konusu olarak işlenmiş ve dilbilgisi konularından önce sistematik olarak tüm becerilerde okuma metni bünyesinde boşluk doldurma tipindeki alıştırmalarla pekiştirici olarak verilmiş mi? dönüşlü fiiller pekiştirilmiştir. Ünitenin diğer iki bölümünde ise zarf fiiller konu olarak işlenmiş, dinleme becerisinde mevcut dilbilgisi konusuna yönelik örnekler verilmiştir.
\end{abstract}

5)Ünitelerde yer alan alıştırmalar Ünite bünyesinde bulunan beceri etkinlikleri ve sonrasında dört temel dil becerisini bulunan alıştırmalar birbirini destekleyici, geliştirici niteliklere geliştirici ve bütünleyici mi?

sahiptir. Okuma becerisi etkinlikleri sonrasinda yazma ve konuşma becerilerini öne çıkaran alıştırmalar dikkat çekmektedir. Ayrıca boşluk doldurma, doğru/yanlış tipi alıştırmalar ile beceri etkinliklerinin anlam boyutuna yönelik etkinlikler de düzenlenmiştir. Meryem Ana Evi isimli okuma etkinliği sonrasında öğrencilerin gerçek iletişim ortamlarına hazırlanması için açık uçlu sorulardan faydalanılmış ve kültürlerarası kıyasların yapılması sağlanmıştır. Ayrıca beceri etkinliklerinin seyahat, turizm, yolculuk gibi konular etrafında şekillendirilmiş olması öğrencilerin hem hazırbulunuşluklarını artırmakta hem de kademeli ilerleyen beceri etkinlikleri ve alıştırmaları için öğrencileri donanımlı hale getirmektedir.

6)Alıştırmalarda (boşluk Ünite bünyesinde yer alan beceri etkinlikleri kapsamında açık uçlu doldurma, eşleştirme, doğru sorular, birden fazla seçeneğin işaretlenebildiği kapsam soruları, yanlış, kısa cevaplı sorular, boşluk doldurma tipi sorular bulunmaktadır. Ünite sonunda çoktan seçmeli sorular vb.) öğrencilerin neler öğrendiğini ölçmek için boşluk doldurma, çeşitlilik sağlanmış mı?

dilbilgisi kurallarını kavratma amaçlı ek tamamlama etkinlikleri ve öğrencilerin kendilerini değerlendirmeleri için 3 sorudan oluşan öz değerlendirme ölçeği bulunmaktadır. Bu kapsamda ünite bünyesinde ulunan alıştırmalar oldukça çeşitli olup öğrencileri monotonluktan uzak tutmaktadir.

7)Ünite bünyesindeki dil Ünite bünyesinde yer alan beceri etkinliklerinde okuma becerisinin becerilerine verilen önem eşit diğer beceri etkinliklerinin nicel olarak diğer beceri etkinliklerinin mi?

önünde olduğu gözlemlenmiştir. Yabancı dil eğitiminin temelini oluşturan okuma becerisi etkinlikleri konuşma ve yazma becerilerini desteklemekledir. Açık uçlu sorular aracılığı ile öğrencilerin duygu, düşünce ve fikirlerini azılı ve sözlü olarak ifade etmeleri talep edildiği gözlemlenmiştir. Ayrıca hedef kelimelerin tüm beceri etkinliklerinde kullandırılması özendirilmiştir.

İstanbul Yabancılar İçin Türkçe Seti B2 ders kitabının 1. Ünitesi, ünite değerlendirme ölçütleri kapsamında incelendiğinde ünite içeriğinin kültür aktarımı ilkesi kapsamında zengin içeriklerden faydalandığı, dilin işlevsel özelliklerini öne çıardığı, beceri etkinlikleri sonrasındaki alıştırma tiplerinde monotonluktan uzak oldukça zengin içeriklerin kullanıldığı gözlemlenmiştir. Okuma metinleri ve diğer beceri etkinlikleri, öğrencilerin ilgisini çekecek konular etrafında yapılandırılmış olup metinler öğrenciyi okumaya teşvik edici yapıdadır. Kalıp sözler, atasözleri ve mecazlar açısından zengin bir içeriğe sahip olan beceri etkinlikleri özellikle okuma metinleri özelinde öğrencilerin $C$ seviyesi için hazırlayıcı niteliktedir. Bu kapsamda, okuma metinleri B2 düzeyinin biraz üstünde hazırlanmış çeşitli kalıp söz ve mecazlarla zenginleştirilmiştir. Ünite bünyesinde bulunan beceri etkinliklerinden okuma becerisi öne çıkmış gibi görünse de metin sonrasındaki alıştırmalarla konuşma 
ve yazma becerileri oldukça fazla desteklenmiştir. Yazma becerisinin yabancı dil eğitiminde öğrenilmesi en zor becerilerden biri olduğu düşünüldüğünde bu durum öğrenci açısından oldukça faydalıdır.

Tablo 2

İstanbul Yabancılar İçin Türkçe Seti B2 Ders Kitabı 2.Ünitesinin (Geçmişten Günümüze) Ünite Değerlendirme Ölçütleri Kapsamında Değerlendirilmesi

\begin{abstract}
1)Ünitede yer alan görseller Ünite bünyesinde yer alan görseller ünite isminden de anlaşılacağı metin içeriğine ve hedef kültüre gibi geçmişteki ve günümüzdeki iletişim araçlarını incelemektedir. ait öğglerin aktarımına uygun Teknoloji, internet ve sosyal medya konularının görsellerle $\mathrm{mu}$ ? destelendiği gibi geçmişte yaygın olarak kullanılan telgraf, mektup vb. iletişim araçları da görsellerle desteklenmiştir. Ayrıca bu görsellerle ilgili eşleştirme etkinliği de düzenlenmiştir. Kültür aktarımına yönelik hem hedef kültürün hem de dünya kültürünün öğelerinden faydalanılmıştır. Ülkemizde yer alan müzeler Almanya ve Fransa'da yer alan müzelerle ilgili bir metin verilmiş ve içerikle ilgili görsellerle bu metin desteklenmiştir.

2)Ünitede yer alan temalar Ünite teknoloji ve iletişim teması etrafında yapılandırılmış olup öğrencilerin iletişim ihtiyaçlarına öğrenciler bu konu ve alt başlıklarına has araçları hayatın her ve sosyal hayata uygun mu? anında kullanmaktadırlar. Bu kapsamda beceri etkinlikleri için seçilen iletişim ve teknoloji konuları öğrencilerin gerçek hayat iletişimleri açısından oldukça isabetlidir. Sosyal medya konusunun da işlendiği ünite etkinlikleri öğrencilerin ilgi alanlarına hitap etmekte ve içeriği monotonluktan uzaklaştırmaktadır. Ayrıca gerçek hayat iletişimleri açısından beceri etkinlikleri açık uçlu sorular, boşluk doldurma etkinlikleri vb. ile öğrenciler desteklenmiştir.
\end{abstract}

3)Ünite bünyesindeki metinler Teknoloji ve iletişim konularının işlendiği ünite bünyesinde anlaşılır bir dille ve okumaya öğrencilerin doğrudan ilgi alanına hitap eden sosyal medya özendirici bir şekilde yazılmış üzerinde durulmuş ve temel beceri etkinlikleri gerçek iletişim mi?

ortamlarını örnekleyen işlevsel yapı üzerine şekillendirilmiştir. Okuma metinleri ve beceri etkinlikleri birbirlerini tamamlayıcı ve bütünleyici biçimde ilerlediği için içerikler birbirini bütünleyici niteliklere sahiptir.

4)Ünitede yer alan metinler Ünite kapsamında fiil çatısı konusu ve zarf fiiller konusu dilbilgisi konularını işleyici ve anlatılmaya devam edilmiştir. Beceri etkinlikleri kapsamında sistematik olarak tüm becerilerde aşmalı olarak bu konular işlenmeye devam edilmiştir. Boşluk pekiştirici olarak verilmiş mi? doldurma alıştırmalarında zarf fiiller ve fiil çatısına yönelik alıştırmalar sunulmuş öğrencilerin bu alıştırmaları yapılandırmaları talep edilmiştir.

5)Ünitelerde yer alan alıştırmalar İletişim ve teknoloji konuları etrafında yapılandırılan beceri dört temel dil becerisini etkinlikleri bir birlerini bütünleyici ve destekleyici niteliktedir. geliştirici ve bütünleyici mi? "Çocukluğumdan Bugüne Teknoloji" isimli okuma becerisi etkinliği sonrasında bulunan alıştırmalarda konuşma becerisine yönelik sorularla birlikte kelime haznesini geliştirmeye yönelik etkinlikler de bulunmaktadır. Konuşma ve yazma becerisi etkinlikleri de konu olarak benzer temaları içermekle birlikte öğrencilerden açık uçlu sorularla iletişim ve teknoloji konularına yönelik güncel ve geçmişe dönük görüşleri talep edilmiştir. Kelime bilgisine yönelik eşleştirme etkinlikleri ile fiilde çatı ve zarf fiil konuları da desteklenmiştir. 


\begin{tabular}{|c|c|}
\hline 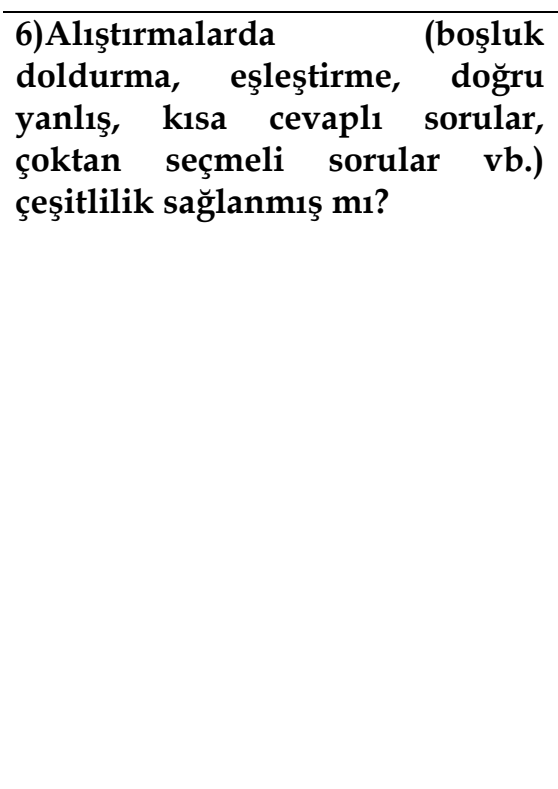 & $\begin{array}{l}\text { Ünite başında görseller ile öğrencinin hazırbulunuşluk düzeyi } \\
\text { artırılmaya çalışlırken bu aşamadan sonra eşleştirme etkinliği } \\
\text { sunulmuştur. Ayrıca okuma metinlerinden sonra iletişim ve } \\
\text { teknoloji konuları ile ilgili eş anlamlı kelimeler için eşleştirme } \\
\text { etkinliği düzenlenmiştir. Doğru/yanlış tipi alıştırmalarında } \\
\text { bulunduğu ünite bünyesinde gerçek iletişim ortamlarının } \\
\text { oluşturulması için açı uçlu sorulardan da faydalanılmıştır. Ünite } \\
\text { sonunda yapılan çalışmaları değerlendirmeye yönelik bir test } \\
\text { bulunmaktadır. Ayrıca öğrencileri kendilerini değerlendirmeleri } \\
\text { için öz değerlendirme ölçeği de mevcuttur. Genel olarak ünite } \\
\text { bünyesinde eşleştirme, açı uçlu soru, boşluk doldurma, } \\
\text { doğru/yanlış tipi alıştırmalardan faydalanılmış ve öğrenci } \\
\text { monotonluktan uzak tutulmaya çalışılmıştır. Yabancı dil eğitimi } \\
\text { açısından önemli bir yere sahip olan boşluk doldurma tipi } \\
\text { alıştırmalar ile öğrencinin hem kelime bilgisi desteklenmiş hem de } \\
\text { konuşma ve yazma becerilerine yönelik gelişimleri } \\
\text { desteklenmiştir. Bu kapsamda tamamlama, hazırlıksız konuşma } \\
\text { vb. çalışmalar yapilmıştır. }\end{array}$ \\
\hline $\begin{array}{l}\text { 7)Ünite bünyesindeki dil } \\
\text { becerilerine verilen önem eşit } \\
\text { mi? }\end{array}$ & $\begin{array}{l}\text { İletişim ve teknoloji konuları etrafında yapılandırılan beceri } \\
\text { etkinlikleri serbest okuma metinlerinin da etkisi ile okuma becerisi } \\
\text { ön plana çımaktadır. Ancak okuma metinleri sonrasındaki } \\
\text { alıştırmalar ile konuşma ve yazma becerileri de desteklenmiştir. Bu } \\
\text { kapsamda okuma becerisine yönelik etkinlikler sayısal olarak } \\
\text { ağırlıkta gibi görünse de metinler sonrasındaki alıştırmalar ile } \\
\text { konuşma ve yazma becerileri durumu dengelemektedir.. }\end{array}$ \\
\hline
\end{tabular}

İstanbul Yabancılar İçin Türkçe Seti B2 ders kitabının 2. Ünitesi (Geçmişten Günümüze) ünite değerlendirme ölçütleri kapsamında değerlendirildiğinde görsellerin ilgi çekici ve beceri etkinlikleri hakkında öğrencilerin önbilgilerini harekete geçirici nitelikte olduğu söylenebilir. Kültür aktarımı ilkesi çerçevesinde yoğun içeriklerin olmadığı ünitede, öğrencilerin gerçek hayat iletişimleri açısından oldukça aktüel konulardan faydalanıldığ gözlemlenmiştir. Bu kapsamda ünite, yer alan beceri etkinlikleri teknoloji ve iletişim konuları etrafında şekillendirilmiştir. İletişim ortamları için örnek teşkil edebilecek yazılı ve sözlü diyaloglar oluşturulmuş ve öğrencinin bu diyaloglara katılması sağlanmıştır. Dil bilgisi konuları önceki ünitedeki içerikleri tamamlayıcı nitelikte olup okuma ve yazma becerilerinde dil bilgisi konularını kapsayan etkinliklerden faydalanılmıştır.

Beceri ekinlikleri, konu ve işleyiş açısından birbiriyle uyum içinde olduğu gözlemlenmiştir. Beceri etkinlikleri sonrasında açık uçlu sorular, boşluk doldurma tipi sorular, doğru/yanlış tipi sorulardan faydalanılmış ve alıştırma tiplerinde zenginlik sağlanmıştır. Ayrıca, ünite sonunda işlenen konulara yönelik değerlendirme soruları ve öz değerlendirme formlarından faydalanılmıştır.

Dil becerilerine ünite içinde verilen önem göz önüne alındığında okuma becerisi için verilen metinlerin sayısal olarak üstün olduğu gözlemlenmiştir. Ancak, bu metinler sonrasında konuşma ve yazma becerilerine yönelik açık uçlu sorular ile konuşma ve yazma becerileri de bir hayli desteklenmiştir. Dinleme becerisine yönelik etkinliklerin ise diğer beceri etkinliklerine göre arka planda kaldığı gözlemlenmiştir. 
Tablo 3

İstanbul Yabancılar İçin Türkçe Seti B2 Ders Kitabı 3.Ünitesinin (Bir Yudum İnsan) Ünite Değerlendirme Ölçütleri Kapsamında Değerlendirilmesi

\section{1)Ünitede yer alan görseller metin içeriğine ve hedef kültüre ait öğelerin aktarımına uygun mu?}

Insanın ruh hali, duygu dünyası ve bu kavramların zekâ ile ilişki durumlarının incelendiği ünitede çok sayıda görsel bulunmaktadır. İlk bölümde verilen görsellerde insanın ruh hallerini yansıtan fotoğraflar bulunmaktadır. Ayrıca İklim ve coğrafyanın insan üzerindeki etkisi görseller aracıll̆̆ı ile sorgulanmıştır. Kişilik ve Karakter isimli okumam metni bünyesinde Erzurumlu İbrahim Hakkı ile ilgili bilgiler verilip kişilik üzerine düşünceleri aktarılmıştır. Bu kapsamda hedef dile ait kültür aktarımı gerçekleştirilmiştir.

2)Ünitede yer alan temalar İnsan teması etrafında şekillenen beceri etkinlikleri coğrafya, öğrencilerin iletişim ihtiyaçlarına iklim, sosyal şartlar ve renklerin insan psikolojisine etkisini ifade ve sosyal hayata uygun mu? etmektedir. Konuşma ve dinleme becerisi etkinliklerinde gerçek hayat iletişimlerine yönelik olarak müziğin insan ruhuna etkisi, Vivaldi'nin Dört Mevsim isimli eserinin ne hissettirdiği gibi etkinlikler düzenlenmiş ve öğrenci için gerçek iletişim ortamları örneklenmiştir.

3)Ünite bünyesindeki metinler İnsanın ruh halleri ve duygusal durumlarının ele alındığı anlaşılır bir dille ve okumaya metinler öğrencilerin ilgisini çekecek içeriklerle tasarlanmış ve özendirici bir şekilde yazılmış gerçek iletişim ortamları için uyarlanmıştır. Türk büyüklerinden $\mathrm{m}$ ? Erzurumlu İbrahim Hakkı ile ilgili bilgiler verilmiş ve metin kültürel açıdan da zenginleştirilerek öğrencilere sunulmuştur. Renkler ve temsil ettikleri sembolik anlamlar, insan ruhuna etkileri öğrencilere sunulmuştur.

4)Ünitede yer alan metinler Ünite kapsamında fiil çatısı ve zarf fiil konularının anlatımına dilbilgisi konularını işleyici ve
sistematik olarak tüm becerileri pekiştirici olarak düzenlenmiş mi?

devam edilmiş olup bunlara ek olarak sanki ve artık edatlarının kullanımı anlatılmıştır. Dinleme ve konuşma etkinliklerinde edatların ve zarf fillerin kullanımı özendirilmiş olup yazma etkinliklerinde de bu yapıların kullanımı hedeflenmiştir. Bu kapsamda boşluk doldurma tipi alıştırmalardan bir hayli faydalanılmıştır.

5) Ünitelerde yer alan alıştırmalar İnsanın ruh hali, duygusu ve bu durumların zekâ ile ilişki dört temel dil becerisini durumlarının incelendiği ünitede beceri etkinlikleri konu, işleyiş geliştirici ve bütünleyici mi? olarak uyum içinde olup etkinlikler birbirlerini destekleyici niteliktedir. Dinleme ve konuşma etkinlikleri genel olarak birbirleriyle etkileşimli olarak tasarlandığı gözlemlenmiştir. Örneğin dinleme etkinliğinde müziğin insanın ruhuna etkileri hakkında bilgiler verilmiş daha sonra konuşma etkinliğinde bir müzik dinletilip etkileri öğrencilere sorulmuştur. Okuma metinlerinde ruhsal zekâ, renklerin insana etkisi aktarılmış yazma etkinliğinde ise duygular ile ilgili bilgiler verilmiştir. 


\begin{abstract}
6)Alıştırmalarda (boşluk Ünite öncesinde yer alan hazırlık çalışmalarında insan ruhunu doldurma, eşleştirme, doğru yansıtan durumlarla ilgili görseller aracılı̆̆ıyla eşleştirme yanlış, kısa cevaplı sorular, etkinliği düzenlenmiştir. Kişilik ve karakter isimli okuma çoktan seçmeli sorular vb.) metninden sonra doğru/yanlış tipi alıştırma kullanılmıştır. çeşitlilik sağlanmış mı?
\end{abstract} becerilerine verilen önem eşit çıktığı gözlemlenmiş olup bu metinler sonrasındaki açık uçlu mi? kapsamda beceri etkinliklerinin konuşma becerisini hem okuma metinleri sonrasındaki sorularla hem de dinleme becerisi etkinlikleri sonrasındaki sorularla diğer becerilere göre daha fazla desteklediği gözlemlenmiştir.

İstanbul Yabancılar İçin Türkçe Seti B2 ders kitabının 3. Ünitesi (Bir Yudum İnsan) bünyesinde yer alan görseller hedef kültürü aktarım açsından uygun olup Erzurumlu İbrahim Hakkı ile ilgili bilgiler verilmiştir. Ünite kapsamındaki beceri etkinlikleri için seçilen renklerin insan üzerindeki etkisi, duygusal zekâ, kişilikkarakter konuları öğrencilerin ilgisini çekecek şekilde dizayn edilmiş ve gerçek hayat iletişimleri açısından öğrencilere yardımcı olacak bir şablonda tasarlanmıştır. Ünite kapsaminda yer alan beceri etkinlikleri birbirlerini bütünleyici ve destekleyici niteliklere sahiptir. Dilbilgisi konuları önceki ünitede olduğu gibi fiil çatısı ve zarf fiiller üzerinden devam ettirilmiştir. Boşluk doldurma tipi, doğru/yanlış tipi, açık uçlu soru tipi ve eşleştirme etkinliklerinden faydalanılan beceri etkinlikleri monotonluktan ve tek tip etkinliklerden uzaktır. Okuma metinlerinin nicel olarak diğer beceri etkinliklerine göre daha önde olduğu gözlemlenmiş olsa da metinlerden sonra öğrenciye yöneltilen sorular, konuşma becerisini diğer becerilere göre daha fazla öne çıkarmaktadır. Ünite yapısı, genel olarak öğrenci ihtiyaçları ve genel standartlar açısından uygun olduğu söylenebilir.

Tablo 4

İstanbul Yabancılar İçin Türkçe Seti B2 Ders Kitabı 4.Ünitesinin (Bana Her Şey Yakışır) Ünite Değerlendirme Ölçütleri Kapsamında Değerlendirilmesi

\footnotetext{
1)Ünitede yer alan görseller Moda teması etrafında yapılandırılan beceri etkinlikleri metin içeriğine ve hedef kültüre görsellerle örtüşmektedir. Kültür aktarımı ilkesi çerçevesinde ait öğelerin aktarımına uygun farklı ulusların geleneksel kıyafetleri sunulmuş; içeriklerin mu? kültürlerarasılık yönü vurgulanmıştır.. Hedef kültüre ait giysilerle ilgili Nasreddin Hoca'nın "Ye kürküm Ye" isimli ünlü fıkrası öğrencilere aktarılmıştır. Ünite bünyesinde moda kavramının dünya kültüründen örnekleri sergilendiği gibi hedef kültürden örnekleri de sergilenmiş olup görseller metinlere uyum içindedir.
} 


\begin{abstract}
2)Ünitede yer alan temalar Öğrencilerin ve günümüz insanının en çok ilgi gösterdiği öğrencilerin iletişim ihtiyaçlarına alanların başında gelen moda kavramı beceri etkinlikleri aracılığı ve sosyal hayata uygun mu? ile çok yönlü olarak incelenmiştir. Kıyafet kişilik ilişkinin işlendiği beceri etkinliklerinden sonra öğrencilerden kendi ülkelerinde benzer durumların olup olmadığı sorgulanmış ve karşılaştırmaların yapılması talep edilmiştir. Genel çerçevede ünitenin öğrencilerin yakından ilgilendiği moda kavram etrafında yapılandırılmış olması ve gerçek hayat iletişimleri ile işlevsel dil kullanımı için faydalı etkinliklerin olması dil öğretimi süreci için oldukça faydalıdır.
\end{abstract}

3)Ünite bünyesindeki metinler Ünite bünyesinde bulunan okuma metinleri öğrencilerin ilgisini anlaşılır bir dille ve okumaya çekecek şekilde yapılandırılmıştır. Ayrıca öğrencileri gerçek özendirici bir şekilde yazılmış iletişim ortamlarına yöneltecek şekilde sorular sorulmuştur. mi? Modaya yönelik öğrencilerin algıları, kendi giyim-kuşam alışkanlıkları, tercihleri sorgulanarak düşüncelerin hedef dilde tartışılmasına zemin oluşturulmuştur.

4)Ünitede yer alan metinler Ünite bünyesinde sıfat fiiller konusu anlatılmış olup diğer beceri dilbilgisi konularını işleyici ve etkinliklerinde aşamalı olarak desteklenmiştir. Özellikle yazma sistematik olarak tüm becerilerde becerisini de içinde barındıran dilbilgisi konularına yönelik pekiştirici olarak verilmiş mi? boşluk doldurma tipi alıştırmalarda uygun sıfat fiillerin kullanılması öğrencilerden talep edilmiştir. Ayrıca ekler aracıllı̆ı ile öğrencilerden sıfat fiil üretmeleri de istenmiştir.

5)Ünitelerde yer alan alıştırmalar Moda kavraminı aktüel bir konu olması sebebiyle ünite dört temel dil becerisini bünyesinde yer alan beceri etkinlikleri daha çok konuşma geliştirici ve bütünleyici mi? becerisinin desteler niteliktedir. "Dikkat Giysileriniz Konuşuyor" isimli okuma metni öncesinde ve sonrasında öğrencilerin metinle ilgili fikir ve düşüncelerini sözlü olarak ifade etmelerini talep eden açık uçlu sorular bulunmaktadır. "Kalıcı Moda Var mı?" isimli okuma metninden önce ve sonra da öğrencilerin görüş ve önerilerini sözlü olarak ifade etmeleri talep edilmiştir. İşleyiş ve içerik bakımından birbiriyle uyum içinde olan beceri etkinlikleri 4. ünite kapsamında konuşma becerisini diğer becerilere nazaran öne çıkarmaktadır.

6)Alıştırmalarda (boşluk Ünite kapsaminda yer alan becer etkinliklerinden hemen sonra doldurma, eşleştirme, doğru yer alan alıştırmalarda oldukça zengin bir içerik hâkimdir. yanlış, kısa cevaplı sorular, "Moda Nedir, Ne Değildir?" isimli okuma metninden sonra çoktan seçmeli sorular vb.) içeriğe yönelik boşluk doldurma tipi, doğru/yanlış tipi ve metin çeşitlilik sağlanmış mı? şıtr metninden sonra ise açı uçlu sorular yer almaktadır. Ayrıca moda kavramına yönelik olarak hazırlanan dinleme kesitleri içinde geçen kavramlar için boşluk doldurma tipi alıştırmalardan faydalanılmış olup açık uçlu sorularla da dinleme becerisi etkinlikleri desteklenmiştir. Konuşma becerisi etkinlikleri sonrasında da moda kavramına yönelik açık uçlu sorulardan faydalanılmıştır. Ünite sonunda boşluk doldurma tipi, açı uçlu soru tipi ve eşleştirme tipi etkinliklerden faydalanılmıştır. Ayrıca öğrencilerin kendilerini değerlendirmeleri için öz değerlendirme formu sunulmuştur. 


\begin{tabular}{|c|c|}
\hline $\begin{array}{l}\text { 7) Ünite bünyesindeki di } \\
\text { becerilerine verilen önem eşi } \\
\text { mi? }\end{array}$ & $\begin{array}{l}\text { Dil öğretim sürecinde kullanılan materyalin ders kitabı olması } \\
\text { sebebiyle mevcut beceri etkinlikleri arasında okuma becerisinin } \\
\text { öne çıktığı gözlemlenmiştir. Bu kapsamda moda gibi aktüel bir } \\
\text { konu etrafında yapılandırılan beceri etkinlikleri öğrenci görüş ve } \\
\text { önerileri ile zenginleştirilmiştir. Ayrıca okuma metinleri ve } \\
\text { dinleme etkinlikleri sonrasında bulunan açı uçlu sorular ile } \\
\text { konuşma becerisi diğer becerilere nazaran öne çıarılmıştır. }\end{array}$ \\
\hline
\end{tabular}

İstanbul Yabancılar İçin Türkçe Seti B2 ders kitabının 4. ünitesi moda kavramı etrafında yapılandırılmıştır. Ünite bünyesinde bulunan görseller, hedef kültür ve dünya kültüründen az sayıda örnek barındırmakta olup kültürlerarasılık ilkesini de gözetmektedir. Ünite bünyesindeki metinler, öğrencilerin ilgisini çekebilecek nitelikte tasarlanmış olup gerçek hayat iletişimleri için oldukça faydalıdır. Bu kapsamda moda kavramının, tüketim algısının, öğrencilerin giyim tercihlerinin gerçek iletişim ortamlarını aratmayacak şekilde sözlü olarak ifade edilmesi sağlanmış; hedef dilde iletişim ortamları oluşturulmuştur. Ünite bünyesinde yer alan beceri etkinlikleri sıfat fiil konusunu aşamalı olarak desteklemiş, alıştırmalarda bu konuya da yer ayrılmıştır. Beceri etkinlikleri kapsamında alıştırma tipi çeşitliliği açısından zenginlik sağlanmış ve alıştırmalar monotonluktan, mekanik tekrarlardan uzaklaşmıştır. Bu kapsamda boşluk doldurma tipi, açık uçlu soru tipi, eşleştirme tipi, doğru/yanlış tipi alıştırmalar bulunmakta olup ünite sonunda genel değerlendirmeler ve öğrenci için öz değerlendirme formu da bulunmaktadır.

\section{Tablo 5}

İstanbul Yabancılar İçin Türkçe Seti B2 Ders Kitabı 5.Ünitesinin (Harikalar Diyarı) Ünite Değerlendirme Ölçütleri Kapsaminda Değerlendirilmesi

\footnotetext{
1)Ünitede yer alan görseller Ünite bünyesinde ülkemizin doğal güzellikleri ve tarihi hakkında metin içeriğine ve hedef kültüre bilgiler verilmiştir. Ayrıca farklı ulus ve kültürlerden mimari ait öğelerin aktarımına uygun yapılar ve tarihi kökenleri ile ilgili bilgilere de yer verilmiştir. Bu mu? kapsamda "Peri Bacaları" isimli okuma metninde Kapadokya ile ilgili görsellerden yararlanılmış, coğrafî ve tarihî bilgiler verilmiştir. Sümela Manastırı isimli okuma metninde de benzer şekilde bölge özellikleri ve tarihi bilgiler öğrencilere aktarılmıştır. Bunlara ek olarak Tac Mahal ile ilgili bilgiler ve yapılış amacı anlatılmıştır. Görseller doğrudan beceri etkinlikleri ve metinlerle ilgili olup hedef kültürün aktarım amacına uymaktadır.

2)Ünitede yer alan temalar Ünite bünyesinde ülkemizin doğal güzellikleri ve mimari öğrencilerin iletişim ihtiyaçlarına güzellikleri etrafında yapılandırıldığı gibi diğer ülkelerden de ve sosyal hayata uygun mu? doğal ve mimari güzelliklerine yer verilmiştir. Bu kapsamda Tac Mahal isimli mimari yapının tarihi ve yapılış hikâyesi aktarılmıştır. Beceri etkinlikleri sonrasında gerçek iletişim ortamlarına yakın atmosferler oluşturmak amaciyla açık uçlu sorulardan faydalanılmıştır. Öğrencilerin kendi ülkelerinde benzeri mimari ve doğal yapıların olup olmadığı sorulmuştur.
} 


\begin{abstract}
3)Ünite bünyesindeki metinler Ünite bünyesinde yer alan okuma metinleri öğrencilerin ilgisini anlaşılır bir dille ve okumaya çekecek şekilde farklı bilgi içeriklerini bünyesinde özendirici bir şekilde yazılmış barındırılmaktadır. Gençler açısından ilgi çeken çeşitli hikâyeleri $\mathrm{m} 1$ ?

bünyesinde barındıran Kapadokya metni turizm ile ilişkilendirilmiştir. Tac Mahal isimli metinde mimari yapının yapılış amacı ve hikâyesi öğrencilere anlaşılır bir dille aktarılmıştır. Ayrıca ünite bünyesinde yer alan hedef kelimeler önceden bağlam içinde kullanılmış ve bu kelimelerin metinler aracılığı ile pekiştirilmesi sağlanmıştır.

4)Ünitede yer alan metinler Dilbilgisi konusu olarak fiil cümleleri, isim cümleleri ve soru dilbilgisi konularını işleyici ve cümlelerinde dolaylı anlatım konusunun işlendiği beceri sistematik olarak tüm becerilerde etkinlikleri birbirlerini destekleyici ve bütünleyici niteliktedir. pekiştirici olarak verilmiş mi? Dilbilgisi konusu çerçevesinde yazma ve konuşma becerisi etkinliklerinin dolaylı anlatım ile gerçekleştirilmesi talep edilmiştir.
\end{abstract}

5)Ünitelerde yer alan alıştırmalar

Ünite bünyesinde yer alan beceri etkinlikleri arasında metinler dört temel dil becerisini aracılığı ile okuma becerisi öne çıkmaktadır. Dineleme ve konuşma geliştirici ve bütünleyici mi? becerisi etkinlikleri sonrasındaki alıştırmalar ile yazma etkinliklerini destekleyen uygulamalar mevuttur. Bunlara ek olarak dilbilgisi alıştırmaları da yazma becerisini desteklemektedir.

6) Alıştırmalarda

(boşluk Peri Bacaları Tac Mahal isimli okuma metinleri sonrasında çoktan doldurma, eşleştirme, doğru seçmeli soru tipi, açık uçlu soru tipi, eşleştirme tipi sorulardan yanlış, kısa cevaplı sorular, oluşan okunan metnin anlaşılıp anlaşılmadığını ölçen sorular çoktan seçmeli sorular vb.) bulunmaktadır. "Mısır Piramitleri", "Kırık, Gizli ve Derin bir Așk çeşitlilik sağlanmış mı?

Hikâyesi" isimli dinleme becerisi etkinliklerinden sonra boşluk doldurma tipi ve açık uçlu sorulardan oluşan alıştırmalar bulunmaktadır. Ayrıca ünite sonunda genel bir değerlendirme etkinliği düzenlenmiş ve öğrenciler için öz değerlendirme formu sunulmuştur. Gelen olarak alıştırma tiplerinde çeşitlilik sağlanmıştır.

8)Ünite bünyesindeki dil Mevcut dil becerisi etkinlikleri içinde okuma metinlerinin sayısal becerilerine verilen önem eşit olarak üstünlüğü görülmektedir. Fakat metinler sonrasında yer mi? alan açık uçlu sorular ile konuşma ve yazma becerisi öne çıkmıştır. Ayrıca dilbilgisi alıştırmalarında da yazma becerisini destekleyen etkinlikler bulunmaktadır.

İstanbul Yabancılar İçin Türkçe Seti B2 ders kitabının 5. ünitesinde ülkemizde ve farklı ülkelerde yer alan doğal ve mimarî güzellikler anlatılıp bilgiler verilmiştir. Bu kapsamda Peri Bacaları, Sümela Manastırı, Taç Mahal görselleri verilmiş olup kültür aktarımı için uygun görseller kullanılmıştır. Ünite bünyesinde kullanılan doğal ve mimarî güzellikler teması, öğrencilerin gündelik hayat içinde ülkemizde sık karşılaştıkları olgular içindedir. Bu kapsamda beceri etkinlikleri, gerçek iletişim ortamlarını destekleyici niteliklere sahiptir.

Ünite kapsamında işlenen "dolaylı anlatım" konusu, diğer beceri etkinlikleri tarafından pekiştirilmiş olup konu anlatımı sonrasında yazma becerisi ile iliş̧kili etkinlikler düzenlenmiştir. Temel dil becerisi etkinlikleri, birbirlerini işleyiş ve içerik bakımından destekleyici nitelikte olup okuma ve dinleme becerisi etkinlikleri sonrasında yazma ve konuşma becerisinin diğer becerilere göre daha fazla desteklendiği gözlemlenmiştir. Beceri etkinlikleri sonrasında alıştırma tiplerinde çeşitlilik sağlanmış ve mekanik tekrarlardan uzak, bireyin yaratıcı gücünün öne çıkarıldığı uygulamalar benimsenmiştir. 
Tablo 6

İstanbul Yabancılar İçin Türkçe Seti B2 Ders Kitabı 6.Ünitesinin Ünite Değerlendirme Ölçütleri Kapsamında Değerlendirilmesi

1)Ünitede yer alan görseller Ünite bünyesinde insan hakkında ilginç bilgiler aktarılmıştır. metin içeriğine ve hedef kültüre İnsan vücudu ve zihni ile ilgili bilgilerin verildiği okuma ait öğelerin aktarımına uygun metninde zihinsel işlemleri temsil eden soyut bir resim, insan mu? vücudu ile ilgili insanın anatomik yapısını temsil eden bir resim kullanılmıştır. Başarabilmek isimli okuma metni öncesinde is içerikle uyumlu olarak Einstein, Edison ve Bill Gates gibi ünlülerin resmi kullanılmıştır. Karagöz ve Hacivat isimli dinleme etkinliğinde içerikle uyumlu olarak Karagöz ve Hacivat görseli kullanılmış olup kültür aktarımı ilkesi çerçevesine görsel ve içerik uyumu gözetilmiştir. Görseller ve içerikler arasında uyum olup kültür aktarımı ilkesi Hacivat ve Karagöz isimli okuma etkinliğinde öne çıkmaktadır.

2)Ünitede yer alan temalar Ünite bünyesinde insan vücudu ile ilgili bilgiler verilmiş, zihin ve öğrencilerin iletişim ihtiyaçlarına rüya ilişkisi aktarılmış, bilim ve sanat dünyasından tanıdığımız ve sosyal hayata uygun mu? kişiler hakkında bilinmeyen bilgiler aktarılmıştır. Öğrencilerin ilgi ve ihtiyaçları çerçevesinde dil öğretim sürecinin hem bilgi hem de kültürel boyutu öne çıarılmıştır. Öğrencileri gerçek iletişim ortamlarına hazırlayıcı içerikler bulunmaktadır.

3)Ünite bünyesindeki metinler anlaşılır bir dille ve okumaya özendirici bir şekilde yazılmış mi?

Ünite bünyesinde yer alan metinler öğrencilerin ilgisini çekip okumaya teşvik edici bir içerikle yazılmıştır. Karagöz ve Hacivat arasında geçen nüktedan diyaloglar kullanıldığı gibi sanat ve bilim dünyasında başarılı olan kişilerin hayatlarından kesitler de aktarılmıştır.

4)Ünitede yer alan metinler Ünite bünyesinde dilbilgisi konusu olarak bağlaçlar konusu dilbilgisi konularını işleyici ve işlenmiştir. Konu anlatımı sonrasında hem yazma becerisini hem sistematik olarak tüm becerilerde de konuşma becerisini destekleyici nitelikte boşluk doldurma pekiştirici olarak verilmiş mi? etkinlikleri düzenlenmiş ve metin içine uygun bağlaçların konulması talep edilmiştir.

5)Ünitelerde yer alan alıştırmalar "İnsan Vücuduyla İlgili Bilmedikleriniz" isimli okuma dört temel dil becerisini metninden sonra açık uçlu sorular kullanılmış ve konuşma geliştirici ve bütünleyici mi? becerisini desteklenmiştir. Karagöz ve Hacivat isimli dinleme etkinliğinden sonra kalıp sözler ve ifadelerin anlamları sorgulanmış olup konuşma becerisi desteklenmiştir. Dinleme becerisi etkinliklerinde ise doğal olarak konuşma becerisi doğrudan desteklenmiştir Yazma becerisi etkinliklerinde okuma metinleri aracılığı ile verilen bilgilerin kullanımı özendirilmiştir. $\mathrm{Bu}$ kapsamda temel dil becerilerine ait etkinlikler birbirlerini destekleyici niteliktedir.

6)Alıştırmalarda (boşluk Beceri etkinlikleri kapsamında yer alan hazırlık çalışmalarında doldurma, eşleştirme, doğru çoktan seçmeli alıştırmalar ve eşleştirme etkinlikleri yer yanlış, kısa cevaplı sorular, almaktadır. İnsan Vücuduyla İlgili Bilmedikleriniz isimli okuma çoktan seçmeli sorular vb.) metninden sonra açık uçlu sorulardan faydalanılmış ve çeşitlilik sağlanmış mı? eşleştirme etkinliği düzenlenmiştir. Karagöz ve Hacivat isimli dinleme etkinliğinden sonra eşleştirme etkinliği düzenlenmiştir. Ayrıca açık uçlu sorular ve boşluk doldurma etkinlikleri alıştırmalar içinde bulunmaktadır. Genel olarak beceri etkinlikleri sonrasında monotonluktan uzak çeşitlilik açısından oldukça zengin alıştırmalar tercih edilmiştir. 


\begin{tabular}{llrl}
\hline $\begin{array}{l}\text { 7)Ünite bünyesindeki } \\
\text { becerilerine }\end{array}$ verilen önem & dil & Beceri etkinlikleri çerçevesinde okuma metinleri kapsamın \\
mi? & okuma becerisinin ünite kapsamında öne çıtı̆̆ gözlemlenmiştir. & Fakat okuma becerisi sonrasında bulunan alıştırmalar ile \\
& konuşma ve yazma becerileri diğer temel becerilere göre daha \\
& fazla öne çımaktadır.
\end{tabular}

İstanbul Yabancılar İçin Türkçe Seti B2 ders kitabının 6. ünitesinde yer alan okum metinleri ve görseller içerik bakımından uyumlu olup Karagöz ve Hacivat isimli dinleme etkinliği kültür aktarımı yönü ile dikkat çekmektedir. Ünite içinde yer alan beceri etkinlikleri, öğrencilerin ilgi alanlarına hitap eden ünlü kişilerin hayatından kesitler, bilimsel içerikler aktarılarak, yapılandırılmıştır. Bu kapsamda insan vücudu hakkında bilgiler verilmiş, zihin ve rüya ilişkisi açıklanmış, bilim ve sanat alanında başarılı kişilerin ilginç özelliklerinden bahsedilmiştir.

Beceri etkinlikleri edatlar konusunu aşamalı olarak pekiştirmiştir. Özellikle okuma metinleri içinde edatlara yer verilmiştir. Dilbilgisi alıştırmaları içinde de boşluk doldurma etkinlikleri ile edatlar pekiştirilmiştir. Dil becerileri arasında okuma becerisi öne çıksa da metin sonrasında bulunan alıştırmalar ile konuşma ve yazma becerileri diğer becerilere göre daha fazla desteklenmiştir.

Boşluk doldurma, doğru/yanlış, eşleştirme, çoktan seçmeli, açık uçlu sorular aracılığ 1 ile alıştırma tiplerinde çeşitlilik sağlanmış olup öğrenciler monotonluktan ve mekanik tekrarlardan uzak tutulmuştur. Beceri etkinlikleri, konu ve işleyiş açısından birbiri ile uyumlu olup konuşma ve yazma becerileri diğer beceri etkinliklerine göre daha fazla desteklenmiştir

\section{Tartışma, Sonuç ve Öneriler}

Nitel desenlerden doküman analizinin kullanıldığı bu çalışmada İstanbul Yabancılar İçin Türkçe Öğretim Seti B2 düzeyi ders kitabı analiz edilmiştir. Yabancı dil eğitimi kitapları için uluslararası standartlar ve nitelikler bakımından McGrath'ın (2002) çalışması alan yazın açısından önem arz etmektedir. McGrath (2002), çalışmasında genel görünüm, fiziksel görünüm, içerik, alıştırma ve değerlendirme başlıkları üzerinde durmuştur.

İstanbul Yabancılar İçin Türkçe Seti B2 ders kitabı McGrath (2002) çalışması ve uzman görüşü alınarak düzenlenen Ünite Değerlendirme Ölçütleri kapsamında değerlendirilmiştir. Bulgulara yönelik genel değerlendirme Tablo 7'de betimlenmiştir.

Tablo 7

İstanbul Yabancilar İçin Türkçe Öğretim Seti B2 Düzeyi Ders Kitabının Ünite Değerlendirme Ölçütlerine Göre Analizi

\begin{tabular}{lllllll}
\hline Ünite değerlendirme ölçütleri & \multicolumn{3}{c}{ Ünite Bilgisi } & & & \\
& 1 & 2 & 3 & 4 & 5 & 6 \\
1.Hazırlık çalışması bulunmaktadır. & $\checkmark$ & $\checkmark$ & $\checkmark$ & $\checkmark$ & $\checkmark$ & $\checkmark$ \\
2.İçerik ve görsel uyumludur & $\checkmark$ & $\checkmark$ & $\checkmark$ & $\checkmark$ & $\checkmark$ & $\checkmark$ \\
& & & & & & \\
3.Görsel konumlandırması uygundur. & $X$ & $X$ & $\checkmark$ & $X$ & $\checkmark$
\end{tabular}




\begin{tabular}{|c|c|c|c|c|c|c|}
\hline 4.Güncel aktüel konular işlenmiştir. & $\checkmark$ & $\checkmark$ & $\checkmark$ & $\checkmark$ & $\checkmark$ & $\checkmark$ \\
\hline 5.Etkinlikler dil bilgisi konularını pekiştirmektedir. & $\checkmark$ & $\checkmark$ & $\checkmark$ & $\checkmark$ & $\checkmark$ & $\checkmark$ \\
\hline 6.Etkinlikler temel dil becerilerini bütünleyicidir. & $\checkmark$ & $\checkmark$ & $\checkmark$ & $\checkmark$ & $\checkmark$ & $\checkmark$ \\
\hline 7.Etkinlikler soru tipi çeşitliliğine sahiptir. & $\checkmark$ & $x$ & $\checkmark$ & $\checkmark$ & $\checkmark$ & $\mathrm{X}$ \\
\hline 8.Etkinlikler temel dil becerilerine eșit derecede önem vermiștir. & $\mathrm{X}$ & $\mathrm{X}$ & $\mathrm{X}$ & $X$ & $X$ & $\mathrm{X}$ \\
\hline
\end{tabular}

Uluslararası standartlar ve kitap nitelikleri açısından öğrencinin öngörü gücünü artırmak, hayal dünyasını güçlendirmek, geleceğe yönelik tahminlerde bulunmasını sağlamak amacıyla görseller metnin ya soluna ya da üstüne konumlandırılması benimsenmiştir (Gün ve Şimşek, 2017). Tematik yaklaşım çerçevesinde yapılandırılan ders kitabında görsel konumlandırılması ile ilgili aksaklıklar görülmektedir.

Kültür aktarımı ilkesi kapsamında Karagöz ve Hacivat, Mimar Sinan, Erzurumlu İbrahim Hakkı gibi hedef dilin kültür öğeleri ile ilişkili görsellerden faydalanılırken; farklı ulusların kültürleri ile ilgili bilgiler verilerek öğrenciden kıyaslamalar yapılması istenmiş, kültürlerarasılık ilkesi gözetilmiştir.

Ders kitabı bünyesinde yer alan temel dil becerisi etkinlikleri, öğrenciler için gerçek iletişim ortamları oluşturmaktadır. Öğrencilerin gündelik hayat içinde sık sık karşılaştıkları teknoloji, internet, turizm, seyahat, sanat ve bilim dünyasından ünlü kişiler, beceri etkinliklerinin konusunu oluşturmakta olup dili işlevsel olarak kullandırmayı amaçlayan etkinlikler bulunmaktadır.

Ders kitabında ileri düzeyde Türkçe kullanımı için hazırlık niteliği taşıyan bazı metinleri de bünyesinde barındırmaktadır. Bu metinler; atasözleri, kalıp sözler ve mecazlar bakımından oldukça zengin bir yapıya sahiptir.

İstanbul Yabancılar İçin Türkçe Seti B2 ders kitabı bünyesinde dilbilgisi konuları beceri etkinlikleri ile paralel şekilde ilerlediği gözlemlenmiştir. İşlenen dil bilgisi konusu, temel dil becerisi etkinliklerinde öğrenciye sunularak ilgili konunun özümsenmesine yönelik bir yapılandırma görülmektedir.

Ünite bünyesinde yer alan temel dil becerisi etkinlikleri konu ve işleyiş olarak birbirlerini destekleyici ve bütünleyicidir. Öreğin, ünite bünyesinde işlenen teknoloji ve iletişim araçları hakkında okuma metinleri aracılığıyla kronolojik ve güncel bilgiler verilirken konuşma becerisi etkinliklerinde bu bilgilerin de yardımı ile öğrencilerin görüş ve önerileri alınmıştır. Yazma becerisi etkinliklerinin en sonda yer alması sebebiyle diğer beceri etkinlikleri bünyesinde edinilen bilgilerin yazılı olarak ifade edilmesi ve kullanılması amaçlanmıştır. Aşamalı olarak ilerleyen beceri etkinlikleri bu plan çerçevesinde birbirini sürekli pekiştirmekte ve desteklemektedir.

İstanbul Yabancılar İçin Türkçe Seti B2 ders kitabı bünyesinde temel beceri etkinlikleri arasında okuma metinlerinin hem nicel bakımdan hem de kitap bünyesinde kapladı̆̆ı hacim bakımından öne çıktı̆̆1 gözlemlenmiştir. Okuma becerisi etkinlikleri sonrasında yer alan alıştırmalar bünyesinde yer alan açık uçlu sorular konuşma becerisini öne çıkardığı gözlemlenmiş; ancak diğer alıştırma tiplerinin 
yazma becerisini öne çıkardığı gözlemlenmiştir. Dinleme becerisi etkinliklerinin kitap bünyesinde diğer becerilere kıyasla geri planda kaldığı gözlemlenmiştir.

Temel beceri etkinlikleri sonrasında yer alan alıştırmalar, çeşitlilik açısından oldukça zengin bir yapıya sahiptir. Boşluk doldurma tipi, açık uçlu soru tipi, eşleştirme tipi, doğru yanlış tipi, çoktan seçmeli soru tiplerine sahip olan alıştırmalar, beceri etkinliklerini monotonluktan uzak tutup öğrenciler açısından dil öğretim sürecini zenginleştirmeyi amaçlamadığı söylenebilir. Alıştırmalarda kullanılan soru tipi çeşitliliği öğrencinin temel dil becerilerini aktif olarak kullanmasında olumlu etkilerde bulunurken dil bilgisi konularının da kavranmasında sürecin verimini artıracağı öngörülmektedir. Ayrıca, ünite sonlarında genel alıştırmalarla birlikte öğrenciler için öz değerlendirme formu ile hem öğretmen hem de öğrenci için sürecin ölçme değerlendirme açısından ele alınmasını sağlamaktadır.

\section{Öneriler}

- Yabancı dil olarak Türkçe öğretiminde kullanılan materyallerin temel dil becerileri bağlaminda genelde okuma becerisine yönelik içerikler öne çıkarken diğer dil becerilerine ait içerikler arka planda kaldığı gözlemlenmektedir. Bu kapsamda, materyallerin temel dil becerilerini eşit düzeyde gözetmesi dengeli bir eğitim süreci takip edilmesini sağlayacaktır.

- Yabancı dil olarak Türkçe öğretimine tarihsel süreç içinde ilgi artmış ve Türkçe Öğretim Merkezleri'nin hitap ettiği etnik unsurlarda çeşitlilik göstermeye başlamıştır. Bu kapsamda, öğrencilerin ülkelerine, dil ailelerine göre ders kitaplarının düzenlenmesinin dil öğretim süreçleri açısından faydalı olacağı düşünülmektedir.

- Metin ve görseller dizayn açısından değerlendirildiğinde; görseller metnin ya soluna ya da üstüne konumlandırılması öğrencinin hazırbulunuşluk düzeyini, metin görsel ilişkisi açısından öğrencinin yordama gücünü pozitif etkileyeceği öngörülmektedir.

- Yabancı dil olarak Türkçe öğretiminde kullanılan materyallerin uluslararası standartlar etrafında yapılandırılması materyalin ve eğitim sürecinin verimini artıracaktır.

\section{Kaynakça}

Aksan, D. (1977) Her Yönüyle Dil, Ana Çizgileriyle Dilbilim I. Ankara: TDK Yayınları

Brown, H. D. (1998): Principles of Language Learning and Teaching (4th Edition), Longman. Pearson Education Ltd., London, UK.

Çalık, T. (2001). Türkçe Ders Kitaplarının Biçim ve Tasarımı. Konu Alanı Ders Kitabı İnceleme Kılavuzu, Türkçe 1-8. Ankara: Nobel Yayın Dağıtımı.

Çepni, S. (2007). Araştırma ve proje çalışmalarına giriş (3.Baskı), Pegem A Yayıncılık, Trabzon,

Demirel, Ö, (2005), Konu alanı ders kitabı inceleme, PegemA Yayıncılık, Ankara. https://doi.org/10.14527/9786050370058

Göçer, A., ve Moğul, S. (2011). Türkçe'nin yabancı dil olarak öğretimi ile ilgili çalışmalara genel bir bakış. Turkish Studies, 6(3), 797-8 http:/ / dx.doi.org/10.7827/TurkishStudies.2470

Gün, M., ve Şimşek, R. (2017). Yabancılara Türkçe öğretiminde kullanılan hikâye 
kitaplarının incelenmesi: Yunus Emre Enstitüsü Türkçe Öğretimi A1-A2 Hikâye Seti Örneği.. International Journal of Languages' Education and Teaching 5(3), 502-517. https:// doi.org/10.18298/ijlet.2070

Halis, İ. (2002) Öğretim Teknolojileri ve materyal geliştirme, Nobel Yayınları, Ankara. Türkçe Sözlük (2005) . Ankara: Türk Dil Kurumu Yayınları

Yıldırım A, Şimşek H (2008) Sosyal bilimlerde nitel araştırma yöntemleri (5. Baskı).

Ankara: Seçkin Yayınları

Kurulu, Y. (2019). Yükseköğretim bilgi yönetim sistemi. Yükseköğretim İstatistikleri [https://istatistik. yok. gov. tr/yuksekogretimIstatistikleri/2019 adresinden, 31. https:/ / istatistik.yok.gov.tr/ (erişim tarihi 29.10.2019)

\section{Summary}

\section{Introduction}

Foreign language teaching can be considered as one of the most deep-rooted activities of humanity in the junction of social, political, educational and cultural activities in the historical process. The languages used by human beings are organized within various rules and systems for communication.This organization has separated the growing human population on the earth, the communities that speak different languages. People are thus engaged in learning the language of other communities. In this context, knowing and learning a foreign language is very important today in order to communicate with other human communities and to make socio-cultural interactions..

Geography where Turkey is hosted on the site over the political and social dynamics. Along with these dynamics, there are movements in demographic and sociopolitical elements in our geography. The number of foreigners visiting Turkey has increased greatly. In addition, the number of foreign students who came to our country with scholarship in the last 10 years has increased significantly with the Yurtdiss Türkler ve Akraba Topluluklar Başkanlığı. As the combination of all these factors, the need for education, learning and adaptation has become evident with the mass of millions addressed. teaching Turkish as a foreign language has gained importance in the process.In this context, Turkish Teaching Centers (TÖMER) have been established within the universities.In these institutions, four basic language skills and grammar knowledge are the main components of the process of teaching Turkish as a foreign language. Each TÖMER uses a textbook and a curriculum in the textbook content. Together with these factors, textbooks should have international standards.

\section{Method}

This study is a qualitative research based on the analysis of textbooks used in teaching Turkish as a foreign language through unit evaluation criteria.In this research, document analysis method was used. Document analysis method, the subject to be investigated with the appropriate sources, the resulting data is evaluated to be healthy or not (Çepni, 2007). Document analysis constitutes the analysis of written or printed documents related to the units to be studied (Yıldırım and Şimşek, 2006). Materials used in teaching Turkish as a foreign language as well as all language teaching tools and materials must fullfil international standards. Materials used in teaching Turkish as a foreign language as well as all language teaching tools and materials must meet 
international standards. In this context, general evaluation, physical appearance, content, exercise and evaluation items were created with the criteria in Materials Evaluation and Design for Language Teaching (McGrath, 2002: 240). Expert opinion was taken for this purpose. "Unit evaluation dimension" qualitative evaluation criteria were used as criteria

\section{Results}

In the textbook, it was observed that reading texts were prominent quantitatively among the basic skills activities.

It was observed that the questions included in the exercises after reading skill activities emphasize speaking skills. Other exercise types seem to emphasize writing skills. Listening skills activities were observed to be in the background in the book. In the textbook, it was observed that grammar topics progressed in parallel with skill activities. The subject of grammar is presented to the student in the basic language skills activities and a structuring is made to understand the subject. The textbook is structured within the framework of the thematic approach. There are problems with the design of pictures in the book. The position of the pictures is far from improving the student's predictive power.

The exercises after basic skill activities have a very rich structure in terms of diversity.Exercises with gap filling type, open-ended question type, matching type, correct wrong type, multiple choice question types can be said to not aim to enrich the language teaching process for students by keeping their skill activities away from monotony.The variety of question types used in the exercises may be useful for the student to actively use basic language skills.It is envisaged that the question types will increase the efficiency of the process in understanding the grammar issues. There is also a self-assessment form for students at the end of the unit with general exercises.

\section{Pedagogical Implications}

- Text and visuals are evaluated in terms of design; Positioning the visuals either to the left or on top of the text is predicted to positively affect the level of readiness of the student and the predictive power of the student in terms of the visual relationship of the text.

- Structuring the materials used in teaching Turkish as a foreign language around international standards will increase the efficiency of the material and the educational process.

\section{Araştırmanın Etik Taahhüt Metni}

Yapılan bu çalışmada bilimsel, etik ve alıntı kurallarına uyulduğu; toplanan veriler üzerinde herhangi bir tahrifatın yapılmadığı, karşılaşılacak tüm etik ihlallerde "Cumhuriyet Uluslararası Eğitim Dergisi ve Editörünün” hiçbir sorumluluğunun olmadığı, tüm sorumluluğun Sorumlu Yazara ait olduğu ve bu çalışmanın herhangi başka bir akademik yayın ortamına değerlendirme için gönderilmemiş olduğu sorumlu yazar tarafından taahhüt edilmiştir.

\section{Authors' Biodata/ Yazar Bilgileri}

Ramazan ŞİMŞEK 1989 yılında Sivas'ta doğdu. İlköğretim ve Lise eğitimini Sivas'ta tamamladı. 2014 yılında Cumhuriyet Üniversitesi Eğitim Fakültesi Türkçe 
öğretmenliği bölümünden mezun oldu. 2016 yılında Nevşehir Üniversitesinde Yabancılara Türkçe öğretimi Bilim Dalında yükseklisansını tamamladı. 2019 yılında İnönü Üniversitesi'nde Türkçe Eğitimi alanında doktarasını tamamladı. Nevşehir Hacı Bektaş Veli Üniversitesinde Öğr. Gör. Dr olarak çalışmaktadır.

Ramazan Şimşek was born in Sivas in 1989. He completed his primary and high school education in Sivas. In 2014, he graduated from Cumhuriyet University Education Faculty Turkish Language Teaching Department. In 2016, he completed his master's degree in Nevşehir University, Department of Teaching Turkish to Foreigners. In 2019, he completed his doctorate in Turkish Education at İnönü University. He is working as a "Lecturer Dr." at Nevşehir Hacı Bektaş Veli University.

Tahsin AKTAŞ Başkent Üniversitesi Yabancı Diller Bölümü'nde Profesör olarak çalışmaktadır.

Tahsin Aktaş works as a Professor at Başkent University, Department of Foreign Languages. 